\title{
Tibor Bohdanovský - politická osobnost' z Bohdanoviec
}

\author{
MATÚŠ BÉREŠ
}

\section{Katedra spoločenských vied, Technická univerzita v Košiciach}

Tibor Bohdanovský - political figure from Bohdanovce

Abstract: The paper discusses life of Tibor Bohdanovský - probably the most famous native of town of Bohdanovce in Košice - okolie district. On the other hand, among Bohdanovce's inhabitants, he is almost unknown person. Tibor Bohdanovský (Tibor Schwarz) was born the son of Jewish innkeeper. Later he found himself in anti-Semitic regime and suffered of fascist oppression on territory of the then Hungarian kingdom during the second world war. After being captured by Soviet army, he joined Communist party of Czechoslovakia. In the post-war period he became active member of communist movement which came to power in 1948 and later he participated also in undemocratic policy of the regime, including persecution of kulaks - prosperous peasants. His identity is also very interesting part of the politician's personality, since probably he denied his roots in order to secure his career. Since Tibor Bohdanovský was important part of totalitarian political environment during communist era in Czechoslovakia, his political career is definitely to be revealed and published.

Keywords: Tibor Bohdanovský, Tibor Schwarz, Communist party of Czechoslovakia, Communist party of Slovakia, collectivization, collective farming, antiSemitism, kulak.

DOI: https://doi.org/10.24040/ahn.2021.24.02.160-171

\section{Úvod}

Významné osobnosti politického života sa nezriedka rodia aj v odl'ahlých sídlach, d'aleko na vidieku, mimo metropol a kultúrnych centier. Je to možno práve túžba vymanit' sa z nepriazne osudu a presadit' sa vo vel'kom meste, nezriedka ignorujúc aj morálku či svedomie, ktoré vedú niektorých nadaných jedincov za úspechom. V prípade Tibora Bohdanovského, ktorý je predmetom nasledujúceho textu, to bola zrejme aj dobová stigma etnického pôvodu. Rodený Bohdanovčan - syn židovského krčmára, ktorý v čase komunistického režimu dosiahol na najvyššie úrovne totalitného štátneho aparátu, je dodnes neznámy nielen pre väčšinu obyvatel'ov rodnej obce, ale nie je dostatočne preskúmaný ani vo vedeckej obci. Kvôli tomuto nesúladu, teda relatívne vysokú zastávanú politickú funkciu na jednej strane a jeho nedostatočný odraz v odbornej literatúre i v rodisku na druhej strane, sme sa rozhodli spracovat' jeho osobný, ale najmä profesionálny život. 
Tibor Bohdanovský - politická osobnost’ z Bohdanoviec

\section{Mladost', obdobie holokaustu a druhej svetovej vojny}

Tibor Bohdanovský sa narodil 26. decembra 1920 v Bohdanovciach ${ }^{1}$ do židovskej rodiny miestneho krčmára ako Tibor Schwarz. Priezvisko Schwarz (vrátane rôznych obmien jeho posledných hlások) sa v Bohdanovciach (Bogdani) uvádza už v roku 1835, ked' je v rámci súpisu obyvatel'ov spomenutý Simon Schwartz a Isac Schwartz. ${ }^{2}$ V neskoršom súpise z roku 1857 je uvedený Wolf Schwartz, narodený v roku 1824 a Herschko Schwartz, narodený v roku $1830 .^{3}$ Z roku 1892 sa zachoval zápis o krčmárovi Manó Schwarczovi z Bohdanoviec, ${ }^{4}$ pričom niekedy pred rokom 1918 prevádzkoval krčmu v Bohdanovciach Mór Schwartz. ${ }^{5}$ Ked'že najstarší obyvatelia Bohdanoviec uvádzajú, že Tibor Bohdanovský pochádzal z rodiny krčmára, ${ }^{6}$ pričom sám v poslaneckom dotazníku uviedol, že „rodičia boli maloživnostníci“" ${ }^{\prime 7}$, čo potvrdzuje aj zápis v jeho vojenskom zázname („syn živnostníka bez zamestnancov“8), môžeme predpokladat', že pochádzal práve z rodiny vyššie spomenutého Móra Schwartza. Suseda rodiny Schwarzovcov Eva Kaduková uviedla, že pri návštevách rodnej obce Tibor Bohdanovský navštevoval aj miestny židovský cintorín. Ten je dnes vo vel'mi zanedbanom stave, z čitatel'ných pomníkov však jeden nesie meno Leopolda Engela, ktorý zomrel 13. novembra 1874 a bol švagrom Tiborovho starého otca.

Tibor Bohdanovský po absolvovaní ôsmich tried l'udovej školy v Bohdanovciach študoval na Združenej odbornej škole textilnej v Košiciach, kde absolvoval tri triedy a vyučil sa ako učeň „v textilnom závode ${ }^{\prime 9}$ na Hlavnej ulici v Košiciach v odbore textilný kvalitár. ${ }^{10}$ Obdobie druhej svetovej vojny, ked' Košice so svojím okolím vrátane Bohdanoviec patrili pod územie horthyovského Mad'arského král'ovstva, prežil Tibor Bohdanovský podl'a dotazníka poslanca Národného zhromaždenia „na prácach

\footnotetext{
${ }^{1}$ MANDA, František: Za Tiborom Bohdanovským. In: Rol'nícke noviny. 1996, roč. 67, č. 236, s. 2.

${ }^{2}$ ANNA, Peter et al.: Rukopis monografie o dejinách Bohdanoviec, bez názvu, s. 39.

3 Štátny archív Košice (d'alej ŠA KE), súpis obyvatel'ov Bohdanoviec z roku 1857. In: ANNA, Peter et al.: Rukopis monografie o dejinách Bohdanoviec, bez názvu, s. 26-27.

${ }^{4}$ Magyarország iparosainak és kereskedőinek cím- és lakjegyzéke. Budapest, 1892. In: ANNA, Peter et al.: Rukopis monografie o dejinách Bohdanoviec, bez názvu, s. 31.

5 ŠA KE, fond Obvodný notársky úrad v Bohdanovciach 1893 - 1938. Bohdanovce, Zápisnice obecného zastupitel'stva, rady, finančnej komisie, 1901 - 1934, s. 249. In: ANNA, Peter et al.: Rukopis monografie o dejinách Bohdanoviec, bez názvu, s. 74 .

${ }^{6}$ Rozhovor s Teréziou Vasilovou. Bohdanovce, 21.12. 2019. Rozhovor s Jolanou Krajcárovou. Bohdanovce, 4. 12.2019.

${ }^{7}$ Archiv poslanecké sněmovny Praha (d’alej APS Praha), fond Národní shromáždění ČSR/ ČSSR 1948 - 1968. Tibor Bohdanovský - Dotazník pre člena Národného zhromaždenia, 1959. ${ }^{8}$ Vojenský historický archív Trnava (d'alej VHA TT), fond osobných spisov, 1920. Tibor Bohdanovský - Dotazník.

${ }^{9}$ APS Praha, fond Národní shromáždění ČSR/ČSSR 1948 - 1968. Tibor Bohdanovský - Dotazník pre člena Národného zhromaždenia, 1959.

${ }^{10}$ VHA TT, fond osobných spisov, 1920. Tibor Bohdanovský - Evidenčný list k vojenskej knižke.
} 
na terajšom území Mad'arska a Rumunska. "11 Podl'a dotazníka v jeho vojenskom zázname od roku 1939, ked” sa vyučil, pracoval v textilnom závode v Košiciach. Neskôr, v roku 1941, bol niekol'ko mesiacov nezamestnaný a koncom roka nastúpil do pracovného tábora vo Veszpréme, kde „konal službu v pracovnom útvare mad'arskej armády bez zbrane." 12 V tomto prípade išlo o tábory nútených prác Munkaszolgálát určené pre politicky nespol'ahlivé osoby a Židov, ked'že im ako súčast' protižidovských opatrení nebola umožnená služba v bojových útvaroch armády. Ako súčast' pracovného útvaru bol vyslaný na územie ZSSR na opevňovacie práce, ${ }^{13}$ kde sa koncom júna 1943 dostal do zajatia Červenej armády. V zajatí sa aj politicky organizoval, ked’že v roku 1944 vstúpil do Komunistickej strany Československa. ${ }^{14} \mathrm{Na}$ jeho neskoršie angažovanie sa v Komunistickej strane Slovenska to však nemalo vplyv, ked’že KSS nebola entitou nezávislou na KSČ, ale „súčast'ou Komunistickej strany Československa"15 a len jej územnou organizáciou. Jeho príklon ku komunistickej strane mohol navyše vzniknút' už skôr. Ako píše Ján Pešek, mnohých Židov už v čase ich pobytu v koncentračných táboroch oslovila myšlienka komunizmu ${ }^{16}$ podporená nádejou, že internacionálny komunizmus odstráni antisemitizmus navždy. ${ }^{17} \mathrm{~V}$ zajatí absolvoval Tibor Bohdanovský aj protifašistickú školu a ako dobrovol'ník - politický pracovník IV. ukrajinského frontu sa zúčastnil „národnooslobodzovacieho boja".18

\section{Politická kariéra v komunistickej strane}

Po oslobodení sa prest'ahoval do Košíc a stal sa okresným tajomníkom KSS a podpredsedom Okresného národného výboru Košice (1945 -

\footnotetext{
${ }^{11}$ APS Praha, fond Národní shromáždění ČSR/ČSSR 1948 - 1968. Tibor Bohdanovský - Dotazník pre člena Národného zhromaždenia, 1959.

12 VHA TT, fond osobných spisov, 1920. Tibor Bohdanovský - Evidenčný list k vojenskej knižke, Dotazník.

13 VHA TT, fond osobných spisov, 1920. Tibor Bohdanovský - Návrh na menovanie do prvej dôstojníckej hodnosti.

${ }^{14}$ VHA TT, fond osobných spisov, 1920. Tibor Bohdanovský - Evidenčný list k vojenskej knižke. 15 VARTÍKOVÁ, Marta (ed.): Komunistická strana Slovenska. Dokumenty z konferencií a plén 1944 - 1948. Bratislava : Pravda, 1971, s. 752. In: PEŠEK, Ján: Komunistická strana Slovenska 1948 - 1968. Členstvo, organizácia, vedenie strany. In: Acta historica Neosoliensia. roč. 17, 2014, s. 121.

16 ŽIAK, Miloš: Jewropean. Bratislava : Kalligram, 2004, s. 51. In: ŠROMOVSKÝ, Martin: Židovská otázka na Slovensku (1945 - 1953), Kniha II. Banská Bystrica : Belianum, 2015, s. 56.

${ }^{17}$ HEITLINGEROVÁ, Alena: Ve stínu holocaustu a komunismu. Praha : G plus G, 2007, s. 86. In: ŠROMOVSKÝ, Martin: Židovská otázka na Slovensku (1945 - 1953), Kniha II. Banská Bystrica : Belianum, 2015, s. 56.

${ }^{18}$ APS Praha, fond Národní shromáždění ČSR/ČSSR 1948 - 1968. Tibor Bohdanovský - Dotazník pre člena Národného zhromaždenia, 1959.
} 
1948) ${ }^{19}$, ktorý ako súčast' sústavy novovytvorených národných výborov prevzal právomoc tamojšieho okresného zastupitel'stva. ${ }^{20}$ Následne pôsobil ako predseda Akčného výboru Národného frontu v Košiciach (1948 - 1950). Neskôr sa angažoval aj v krajskom výbore strany. Podl'a zápisníc z rokovaní predsedníctiev Krajského výboru KSS v Košiciach z roku 1950 bol od začiatku roka prítomný na zasadnutiach ako člen sekretariátu, pričom sa zaoberal najmä témou pol'nohospodárstva družstevníctva. Počas skúmaného obdobia 3. januára až 6. júna 1950, ked' sa uskutočnilo 13 zasadnutí, bol na prvých dvoch schôdzach Tibor Bohdanovský v prezenčnej listine uvedený medzi pracovníkmi sekretariátu na tret'om mieste, pričom sa neuplatňovalo abecedné poradie. Od tretieho zasadnutia, ktoré sa uskutočnilo 24. januára 1950, bol uvádzaný spomedzi pracovníkov sekretariátu už vždy na prvom mieste, nad'alej však bez abecedného poradia. Napokon, v zápisnici z rokovania uskutočneného 18. apríla 1950 sa Tibor Bohdanovský uvádza už ako člen predsedníctva KV KSS. ${ }^{21}$ Vo všetkých doteraz preskúmaných zápisniciach vystupoval Tibor Bohdanovský zo všetkých členov sekretariátu najaktívnejšie, mnohokrát bol aktívnejší ako členovia predsedníctva a často referoval viacero bodov programu zasadnutia, zapájal sa do rozpravy a niekedy dopíňal krajského tajomníka strany Ladislava Priesola. V košických štruktúrach strany obsadil neskôr pozíciu okresného tajomníka a následne vedúceho oddelenia pre pol'nohospodárstvo na Krajskom výbore KSS ${ }^{22}$ a bol tiež členom tzv. družstevnej pät'ky v Košiciach, čo bol orgán koordinujúci zakladanie jednotných rol'níckych družstiev (JRD) v obciach Košického kraja v roku $1950 .{ }^{23}$

Ako sme uviedli, Tibor Bohdanovský sa angažoval predovšetkým v sektore pol'nohospodárstva. Zo skúmaného obdobia bol za splnenie takmer všetkých uznesení predsedníctva KV KSS týkajúcich sa pol'nohospodárstva zodpovedný práve on. ${ }^{24} \mathrm{~V}$ rámci kolektivizácie pol'nohospodárstva koordinoval a politicky dozeral na zakladanie JRD v Košickom kraji a tiež „systematicky organizoval politickú a presvedčovaciu

\footnotetext{
19 VHA TT, fond osobných spisov, 1920. Tibor Bohdanovský - Dotazník.

20 ŠUTAJOVÁ, Jana: Historická reflexia vzt'ahov územnej samosprávy a štátu na území Slovenska. In: DOBIAŠ, Daniel - EŠTOK, Gabriel - BZDILOVÁ, Renáta (eds.): Medzi jednotlivost'ou a pospolitost'ou. Košice : UPJŠ, 2016, s. 255.

21 ŠA KE, fond ÚV KSS 09/3, ar. j. 104 - 120. Zápisnice zo zasadnutí predsedníctva Krajského výboru KSS v Košiciach 3. 1.1950 - 6. 6. 1950.

22 BOHDANOVSKÝ, Tibor: Socializácia dediny a l’udia. In: TRUCHLIK, Karol (ed.). Míl'niky na družstevnej ceste - Tridsat' rokov JRD. Bratislava : Ústav marxizmu-leninizmu ÚV KSS, 1979 , s. 162.

${ }^{23}$ BOHDANOVSKÝ, T.: Socializácia dediny a l'udia, s. 165.

24 ŠA KE, fond ÚV KSS 09/3, ar. j. 104 - 120. Zápisnice zo zasadnutí predsedníctva Krajského výboru KSS v Košiciach 3. 1. 1950 - 6. 6. 1950.
} 
prácu“, aby sa docielil vstup rol'níkov do družstiev vrátane určovania politických pracovníkov pre JRD. ${ }^{25}$ Zodpovedný bol však aj za iné úlohy, napríklad spracovávanie výkupných plánov obilia, ${ }^{26}$ no angažoval sa aj v rámci kontraktácie, teda uzatvárania zmlúv o výkupe pol'nohospodárskych produktov od súkromných pestovatel'ov, čo bol vtedy najvýznamnejší spôsob obživy obyvatel'stva na slovenskom vidieku. „Formou kontraktácie uzatvárali rolníci zmluvy o výrobe a dodávkach pol'nohospodárskych výrobkov... "27 Komunistická ideológia však triedneho nepriatel'a našla aj na vidieku. Stal sa ním bohatý gazda, nazývaný tiež dedinský boháč alebo kulak, ktorého režim všemožne zatláčal a znevýhodňoval oproti vlastníkom menšej výmery pôdy. Boli to pritom často bohatí gazdovia, ktorí odmietali vstúpit' do družstiev a režim ich vykresl'oval ako vykorist'ovatel'ov, boháčov a podvodníkov, využívajúc fakt, že „majetkové pomery boli alfou a omegou všetkých vzt'ahov na dedine “.28 Diskriminácia bohatých gazdov sa preto prejavovala aj pri kontraktácii, „....pričom sa malo postupovat' diferencovane podl'a vel'kosti rol'níckych hospodárstiev".29 V praxi to znamená, že bohatý rol'ník musel štátu odviest' v prepočte na rozlohu pôdy viac produkcie (kontingent) ako chudobnejší rol'ník. Navyše, bohatí rol'níci boli zat’ažení aj vyššími daňami, núteným odkúpením strojov, následnými trestami za neobrobenie všetkej pôdy a pod. Ako odznelo v diskusii na pracovnej porade vedúcich justičných pracovníkov v Košiciach 23. októbra 1953, „kulakovi sa musí dat' taký kontingent, aby ho nemohol splnit', a potom ho postavit' pred súd“. ${ }^{30}$ Na tejto politike komunistického režimu aktívne participoval zo svojej funkcie aj Tibor Bohdanovský. Z tohto obdobia sú prístupné zápisy zo zasadnutí KV KSS v Košiciach, kde referuje o výkupoch pol'nohospodárskych strojov ${ }^{31}$ alebo o organizovaní posedenia „so súdruhmi, ktorí sa najlepšie osvedčili v tejto kontraktačnej kampani".32

V roku 1951 Tibor Bohdanovský kariérne postúpil a dva roky pôsobil v Banskej Bystrici ako vedúci tajomník Krajského výboru KSS. Išlo

\footnotetext{
25 ŠA KE, fond ÚV KSS 09/3, ar. j. 116. Zápisnica zo zasadnutia predsedníctva Krajského výboru KSS v Košiciach 2. 5. 1950. s. 13.

${ }_{26}$ ŠA KE, fond ÚV KSS 09/3, ar. j. 119. Zápisnica zo zasadnutia predsedníctva Krajského výboru KSS v Košiciach 3. 6. 1950. s. 1 - 2.

${ }^{27}$ HLAVOVÁ, Viera: Kulak - triedny nepriatel'. Bratislava : VEDA, 2010, s. 35.

${ }^{28}$ HLAVOVÁ, V.: Kulak - triedny nepriatel', s. 14.

${ }^{29}$ HLAVOVÁ, V.: Kulak - triedny nepriatel', s. 35.

${ }^{30}$ NA Praha, fond ÚV KSČ - 29. Komisie právní, ar. j. 154. Správy o prieskume súdnictva v slovenských krajoch. In: HLAVOVÁ, V.: Kulak - triedny nepriatel', s. 35.

31 ŠA KE, fond ÚV KSS 09/3, ar. j. 106. Zápisnica zo zasadnutia predsedníctva Krajského výboru KSS v Košiciach 24. 1. 1950. s. 3.

32 ŠA KE, fond ÚV KSS 09/3, ar. j. 107. Zápisnica zo zasadnutia predsedníctva Krajského výboru KSS v Košiciach 1. februára 1950. s. 24.
} 
o obdobie prípravy a realizácie d’alšej z represívnych akcií totalitného režimu - akcie $\mathrm{K}$ (kulak). V rámci nej mali byt' dedinskí boháči po nespravodlivých procesoch uväznení, zbavení majetku a s celou rodinou vyst'ahovaní mimo svojho okresu so zákazom vrátit’ sa spät'. Realizáciu akcie upravoval prísne tajný dokument - „Smernica ministra národnej bezpečnosti, vnútra a spravodlivosti zo dňa 22. októbra 1951 o úprave pomerov rodinných príslušníkov odsúdených dedinských boháčov ".33 Vyst'ahovanie sa teda týkalo nielen odsúdeného, ale aj celej rodiny, s ktorou zdiel'al domácnost' vrátane práceneschopných starých rodičov či sluhov (čel'ade). Všetky tieto osoby sa v dokumentoch ŠtB súhrnne označovali ako „rodinný celok“. ${ }^{34}$ Vyst'ahovaní kulaci boli pracovne zarad'ovaní na štátne majetky alebo JRD podl'a ich ubytovacích možností. $\mathrm{Z}$ tohto obdobia je zachovaná korešpondencia medzi Tiborom Bohdanovským a vtedajším ministrom národnej bezpečnosti Karolom Bacílkom. Krajský tajomník strany Bohdanovský zaslal 3. apríla 1952 ministrovi list s uznesením krajského predsedníctva KSS, ktoré súhlasilo $\mathrm{s}$ tým, „aby dedinskí boháči z kraja Banská Bystrica boli vyvezení na ČSŠM $v$ Čechách z tých príčin, že v našom kraji nieto ubytovacích možností". 35 Odpoved' ministra Bacílka však bola negatívna: „Vážení súdruhovia! [...] Ide o tak závažnú vec, že sa k nej budete musiet' ešte raz vrátit’ a dôkladne ju z hl'adiska politickej línie Strany preskúmat'. Niet ešte u nás na dennom poriadku otázka likvidácie kulactva ako triedy. To za prvé. A za druhé nebude ani vtedy, ked' táto otázka bude aktuálnou, možné, aby ste $v$ tak závažnej veci prijímali uznesenie len z hl'adiska miestnych záujmov." 36 Tibor Bohdanovský teda zo svojich vysokých regionálnych funkcií aktívne participoval aj na perzekúciách a zverstvách predchádzajúceho nedemokratického režimu. Akcia K (kulak) trvala v dvoch fázach od novembra 1951 do augusta 1953 a celkom bolo vyst'ahovaných minimálne 1629 rodín (rodinných celkov), väčšinou v rámci Česka a zo Slovenska do Česka, z toho prinajmenšom 77 rodín z Banskobystrického kraja. ${ }^{37}$

V roku 1953 v rámci personálnych čistiek v Komunistickej strane Slovenska obsadil Tibor Bohdanovský v Košiciach post vedúceho krajského

\footnotetext{
33 Směrnice ministrů národní bezpečnosti, vnitra a spravedlnosti ze dne 22. ř́ijna 1951 o úpravě poměrů rodinných př́slušníků odsouzených vesnických boháčů. Dostupné na internete: <https://is.muni.cz/th/af3vk/Prilohy.pdf> [cit. 2021-07-08].

34 JECH, Karel: Soumrak selského stavu 1945 - 1960. Praha : Ústav pro soudobé dějiny AV ČR, 2001, s. 77.

${ }^{35}$ Archív Ministerstva vnútra Českej republiky (d'alej AMV ČR), fond A2/1 , ar. j. 1365, šk. 49. Listy Tibora Bohdanovského Karolovi Bacílkovi z 3. a 15. 4. 1952.

${ }^{36}$ AMV ČR, fond A2/1 , ar. j. 1365, šk. 49. Listy Tibora Bohdanovského Karolovi Bacílkovi z 3. a 15. 4. 1952.

${ }^{37}$ HLAVOVÁ, V.: Kulak - triedny nepriatel', s. 63 - 64.
} 
tajomníka strany, ${ }^{38}$ ked' bol dovtedajší tajomník Ladislav Priesol na základe vykonštruovaných obvinení zo svojej funkcie stiahnutý. ${ }^{39} \mathrm{~S}$ rovnakou funkciou sa teda presunul z Banskej Bystrice spät' do Košíc. Poslancom Národného zhromaždenia republiky Československej bol v rámci volebného obdobia 1954 - 1960. Kandidoval za volebný obvod Nové Zámky - Komárno, pričom sl’ub zložil až 8. júla 1959, ked' nahradil zosnulého poslanca Jozefa Malíka. ${ }^{40}$ V rokoch 1960 - 1964 zastával post námestníka ministra pol'nohospodárstva ČSSR ${ }^{41}$ počas pôsobenia ministrov Lubomíra Štrougala, Vratislava Krutinu a Jiř́ího Buriana. Následne pôsobil ako poslanec Slovenskej národnej rady v rámci volebného obdo-

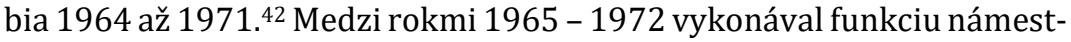
níka ministra pol'nohospodárstva a výživy Slovenskej socialistickej republiky, ked' pozíciu ministra zastával Ján Janovic, a neskôr sa stal členom ústredného výboru Zväzu družstevných rol'níkov ČSSR (1972 1982), odkial' odišiel do dôchodku. ${ }^{43}$ V rokoch 1955 - 1958 študoval na Vysokej politickej škole pri ÚV KSSZ v Moskve. ${ }^{44}$

Jeden z bratov Tibora Bohdanovského Ladislav sa počas vojny, podobne ako Tibor, nenachádzal v rodnej obci. Podl'a pamätníčky Evy Kadukovej (suseda rodiny Schwarzovcov) sa vzdelával niekde na území dnešného Mad'arska, kde aj ostal a po vojne sa rovnako ako jeho brat angažoval v komunistickej politike. Po potlačení revolúcie v Mad'arsku v roku 1956 sa dostal do nepriazne vtedajšieho politického prostredia a bol nútený emigrovat'. 45 Túto spomienku potvrdil Tibor Bohdanovský, ktorý vo svojom životopise uviedol, že sa s bratom rozišli v roku 1938,

\footnotetext{
38 ŠPILKA, Jozef: Mocensko-politické zápasy vo vedení Komunistickej strany Slovenska v rokoch 1950 - 1953. In: Historický časopis. [online], 2016, roč. 64, č. 3, s. 482. Dostupné na internete: <http://www.historickycasopis.sk/pdf/Historicky_casopis_3_2016.pdf> [cit. 2019-12-08].

39 ŠA KE, fond ÚV KSS 09/3, ar. j. 124. Zápisnica zo zasadania mimoriadneho predsedníctva Krajského výboru KSS v Košiciach 30. 11. 1952.

40 Poslanecká sněmovna Parlamentu České republiky - Tibor Bohdanovský. [online]. Dostupné na internete: <http://www.psp.cz/sqw/detail.sqw?org=284\&id=717> [cit. 201912-16].

${ }^{41}$ MANDA, F.: Za Tiborom Bohdanovským, s. 2.

42 Stenografický záznam z 2. schôdze Slovenskej národnej rady 17. septembra 1964. [online]. Dostupné na internete: <https://www.psp.cz/eknih/1964snr/stenprot/002schuz/s0020 01.htm> [cit. 2020-10-28]. V súvislosti s politickými zmenami, ktoré nasledovali po vpáde vojsk Varšavskej zmluvy do Československa v roku 1968 sa nasledujúce vol'by do SNR nekonali v roku 1968, ale až v roku 1971, čo umožnil prijatý ústavný zákon. Ústavný zákon č. 117/1969 Zb. [online]. Dostupné na internete: <https://www.zakonypreludi.sk/zz/1969117> [cit. 2020-10-25].

${ }^{43}$ MANDA, F.: Za Tiborom Bohdanovským, s. 2.

${ }^{44}$ APS Praha, fond Národní shromáždění ČSR/ČSSR 1948 - 1968. Tibor Bohdanovský - Dotazník pre člena Národného zhromaždenia, 1959.

${ }^{45}$ Rozhovor s Evou Kadukovou. Bohdanovce, 9. 6. 2020.
} 
ked' odišiel do mad'arského mesta Tálya, odkial' pochádzala ich matka, a kde sa vyučil za mlynárskeho pracovníka. Po vojne, ktorú prežil rovnako ako jeho brat Tibor v koncentračnom tábore, ostal v Mad'arsku, kde sa oženil a v roku 1956 „pri kontrarevolúcii bol vyhodený zo zamestnania, že bol vel'ký «rákošiovec»". Následne emigroval. ${ }^{46}$ Podl'a Evy Kadukovej boli ciel'om jeho emigrácie Spojené štáty americké, odkial' ešte v 80. rokoch prišiel navštívit' spolu s bratom Tiborom Bohdanovce a miestny židovský cintorín. ${ }^{47} \mathrm{O}$ jeho d'alšom osude už nemáme informácie.

Ako uviedla Eva Kaduková, Tibor Bohdanovský sa so svojím bratom po emigrácii stretával vo Viedni, pričom bol sledovaný Štátnou bezpečnost'ou. V období normalizácie to bolo podl'a jej spomienok dôvodom na ukončenie jeho kariéry, ked’ v roku 1972 skončil vo funkcii námestníka ministra pol'nohospodárstva ČSSR a stal sa členom Ústredného výboru Zväzu družstevných rol'níkov ČSSR, čo bol odborový zväz družstevníkov. ${ }^{48}$ Toto môžeme chápat' ako preradenie - odsunutie nepohodlného funkcionára na menej významnú a najmä menej exponovanú pozíciu, čo bolo $\mathrm{v}$ danom období zaužívané $\mathrm{v}$ prípade starších alebo nepohodlných kádrov. Uvedenú domnienku potvrdzuje aj fakt, že funkcia, ktorú Tibor Bohdanovský v ZDR zastával, nebola volená, ale obsadzovaná priamo $\mathrm{z}$ rozhodnutia strany. Verziu o ukončení politickej kariéry z dôvodu stykov s bratom potvrdil aj Július Medved', nástupca Tibora Bohdanovského na pozícii námestníka pol'nohospodárstva a výživy SSR. ${ }^{49}$ Nedisponujeme d'alšími informáciami, ktoré by potvrdzovali túto hypotézu, Tibor Bohdanovský však téme svojho brata venoval jeden odsek zo životopisu, ktorý je súčast'ou jeho vojenského záznamu, ${ }^{50}$ išlo teda o dôležitú kapitolu, ktorú zrejme nemohol opomenút'.

RSDr. Tibor Bohdanovský, CSc. zomrel bez potomkov vo veku nedožitých 76 rokov 5. októbra 1996 v Bratislave. ${ }^{51}$ Je autorom monografie o rozvoji pol'nohospodárstva $v$ hornatých oblastiach na Slovensku, autorom a spoluautorom článkov v zborníkoch, novinách a časopisoch venovaných pol'nohospodárstvu v slovenskom i mad'arskom jazyku a jeho prejavy boli niekol'kokrát publikované v tlači.

\section{Identita Tibora Bohdanovského}

Za najdôležitejšiu zložku identity Tibora Bohdanovského považujeme jeho židovský pôvod, ktorý naznačujú aj mená a priezviská jeho

\footnotetext{
${ }^{46}$ VHA TT, fond osobných spisov, 1920. Tibor Bohdanovský - Životopis.

${ }^{47}$ Rozhovor s Evou Kadukovou. Bohdanovce, 9. 6. 2020.

${ }^{48}$ Rozhovor s Evou Kadukovou. Bohdanovce, 9. 6. 2020.

${ }^{49}$ Rozhovor s Júliusom Medved'om. Bratislava, 16. 7. 2020.

${ }^{50}$ VHA TT, fond osobných spisov, 1920. Tibor Bohdanovský - Životopis.

${ }^{51}$ MANDA, F.: Za Tiborom Bohdanovským, s. 2.
} 
rodičov, ked'že Tibor bol synom dedinského krčmára - Žida Móra Schwarza a Šarloty, rodenej Pasternak(ovej). Navyše, v rámci svojho vojenského záznamu uviedol v kolónke náboženstvo $\mathrm{v}$ dvoch rôznych dotazníkoch explicitne „izrael“.52 V období narodenia a mladosti Tibora Schwarza spadali bohdanovskí Židia pod rabinát v Ždani, 53 pričom v Bohdanovciach bol a stále ešte je židovský cintorín. Tibor si zmenil židovské priezvisko Schwarz na slovenské Bohdanovský pravdepodobne v čase pred obnovením Československa, ked' sa podiel'al na oslobodzovaní ako politický pracovník - dobrovol'ník v rámci 4. ukrajinského frontu. Ako sám uviedol vo svojom životopise, „v novembri 1944 dostali sme sa do Užhorodu, kde som pracoval na vojenskom velitel'stve. Ešte tento mesiac sme sa premiestnili pod Dargov, obec Hažín, okres Michalovce, kde som bol pridelený $k$ vojenskej vysielačke. Každý deň $2 x$ sme vysielali správy tesne z blízkosti frontovej línie. [...] K zmene mena došlo tak, že pri rádiostanici som používal to meno, ktoré potom som si aj ponechal".54 Z uvedeného by sa mohlo zdat', že si Tibor Bohdanovský ponechal zmenené priezvisko z dôvodu zvyku, ktorý nastal po jeho dlhšom používaní. Za uvedených okolností mohlo byt' používanie tohto priezviska užitočné vzhl'adom na fakt, že Bohdanovce sú obec ned'aleko Dargovského priesmyku, do oblasti ktorého bolo smerované vysielanie. Napriek tomu sa však nazdávame, že k zmene priezviska došlo z kariérnych dôvodov, aby sa tým čiastočne maskoval jeho židovský pôvod, pričom používanie tohto priezviska počas vojenského vysielania mohlo podporit' snahu o zmenu a Tibor tým mohol získat' oficiálne prezentovatel'ný argument pre zmenu priezviska, ktorý sa navyše týkal jeho spoločensky vel'mi významnej životnej kapitoly - účasti na oslobodení Československa. Domnienku, že k zmene priezviska Tibora Bohdanovského došlo z kariérnych dôvodov, podporil aj jeho bývalý spolupracovník a nástupca na pozícii námestníka ministra pol'nohospodárstva a výživy SSR Július Medved'.55 0 zmenách židovských priezvisk, fenoméne rozšírenom v povojnovom období, píše vo svojej monografii o dejinách Židov v Košiciach Ján Mičko: „V snahe zamaskovat' mad'arskýa židovský pôvod dochádzalo mnohokrát aj ku zmene rodinného priezviska." ${ }^{\text {"5 }} 0$ zmenách priezvisk komunistov - Židov píše Ján Pešek v knihe Komunistická strana Slovenska - dejiny politického

\footnotetext{
52 VHA TT, fond osobných spisov, 1920. Tibor Bohdanovský - Záznam o službe.

${ }^{53}$ A Magyar Korona országainak helységnévtára (1892). [online]. Dostupné na internete: $<$ https://library.hungaricana.hu/hu/view/NEDA_1892_helysegnevtar/?pg=1151\&layout=s\&query=Garb\%C3\%B3cz> [cit. 2020-10-14].

${ }^{54}$ VHA TT, fond osobných spisov, 1920. Tibor Bohdanovský - Životopis.

55 Rozhovor s Júliusom Medved'om. Bratislava, 16. 7. 2020.

56 MIČKO, Ján: Dejiny Židov v Košiciach a ich spolupráca s ekumenickým spoločenstvom. Košice : SSS, s. 124.0 zmenách židovských priezvisk pozri aj: Kol.: Slovník židovských osobností Košíc a okolia. Košice : Verejná knižnica Jána Bocatia v Košiciach, 2001.
} 
Tibor Bohdanovský - politická osobnost’ z Bohdanoviec

subjektu. ${ }^{57}$ Problematický vzt'ah komunistickej moci v Československu voči Židom v komunistickej strane, tzv. vládny antisemitizmus, ${ }^{58}$ sa prejavil predovšetkým v období prebiehajúceho vykonštruovaného procesu s Rudolfom Slánskym a spol., kde spomedzi 14 obžalovaných komunistických funkcionárov malo židovský pôvod $11 \mathrm{z}$ nich. Navyše, proces $\mathrm{s}$ „vedením protištátneho spikleneckého centra" so sebou priniesol vlnu antisemitizmu v slovenskej verejnosti. ${ }^{59}$ Vzhl'adom $\mathrm{k}$ tomu je zaujímavý zápis z rokovania predsedníctva KV KSS z 21. februára 1950. Počas rokovania sa predsedníctvo strany zaoberalo „prepustením“ priestorov židovských stravovacích zariadení v centre Košíc na Roosveltovej ulici pre detský obchodný dom Pionier. Židovská náboženská obec podl'a zápisu tento proces zdržovala a ako napokon uviedol krajský tajomník Ladislav Priesol, „hovoril som so súdruhom Husákom v tejto veci a on mi povedal, aby sme to jednoducho obsadili“"60 Najzaujímavejšie na tomto prípade však je, že Tibor Bohdanovský, hoci bol na rokovaní prítomný a na zasadaniach bol vždy mimoriadne aktívny, k tejto téme sa podl'a zápisnice ani slovom nevyjadril. Podl'a spomienok susedy Schwarzovcov sa Tibor Bohdanovský navonok ani v súkromí neprejavoval ako veriaci žid, podobne sa vyjadrili jeho niekdajší spolupracovníci Július Medved' z ministerstva pol'nohospodárstva a výživy a František Manda zo Zväzu družstevných rol'níkov ČSSR, kde Tibor Bohdanovský pôsobil od roku 1972 ako člen ústredného výboru. Obaja však potvrdili, že počas svojej kariéry vyhl'adával a udržiaval osobné kontakty s kolegami židovského pôvodu. ${ }^{61}$

V rámci poslaneckého dotazníka v odseku znalostí jazykov Tibor Bohdanovský uviedol „slovenský, ruský, mad'arský“.62 Ked'že absolvoval trojročné štúdium v Sovietskom zväze a bol významným komunistickým funkcionárom, ruštinu ovládal určite dobre. Mad'arčina bola podl'a susedy Schwarzovcov Evy Kadukovej jeho materinským jazykom, a vo svojich spomienkach tiež uviedla, že počas návštev u niekdajších susedov v Bohdanovciach sa s nimi rozprával po mad'arsky. ${ }^{63}$ Vo svojom vojenskom zázname v odseku znalostí cudzích jazykov uviedol pri mad’arčine

\footnotetext{
57 PEŠEK, Jan: Komunistická strana Slovenska - dejiny politického subjektu. Bratislava : VEDA, 2012, s. 31.

58 ŠROMOVSKÝ, Martin: Židovská otázka na Slovensku (1945 - 1953), Kniha II. Banská Bystrica : Belianum, 2015, s. 106.

59 ŠROMOVSKÝ, Martin: Židovská otázka na Slovensku (1945 - 1953), Kniha II. Banská Bystrica : Belianum, 2015, s. 63.

60 ŠA KE, fond ÚV KSS 09/3, ar. j. 110. Zápisnica zo zasadnutia predsedníctva Krajského výboru KSS v Košiciach 21. 2. 1950. s. 23.

${ }^{61}$ Rozhovor s Júliusom Medved'om. Bratislava, 16. 7. 2020. Rozhovor s Františkom Mandom. Bytča, 20. 8. 2020.

${ }^{62}$ APS Praha, fond Národní shromáždění ČSR/ČSSR 1948 - 1968. Tibor Bohdanovský - Dotazník pre člena Národného zhromaždenia, 1959.

${ }^{63}$ Rozhovor s Evou Kadukovou. Bohdanovce, 9. 6. 2020.
} 
ako spôsob nadobudnutia jej znalosti „od malička“.64 Navyše, medzi bibliografiou Tibora Bohdanovského nachádzame tri články v mad'arčine $\mathrm{v}$ novinách pre mad'arsky hovoriacich rol'níkov Szabad Földműves (Slobodný rol'ník). ${ }^{65}$ Napokon, je známe, že Židia sa v Uhorsku od 19. storočia vel'mi l'ahko mad'arizovali a prechádzali z používania nemčiny na mad'arčinu spravidla z ekonomických a kariérnych dôvodov. Ako uviedol v roku 1883 Gusztáv Beksics, „Židia sa masovo pomad'arčujú. Iba ich malé percento ešte nevie po mad'arsky. [...] Židia, ktorí sa ešte nepomad'arčili, vo výkazoch vzt'ahujúcich sa na priemysel a obchod, uvádzajú v rubrike Nemcov. Ale ovel'a skôr sa pomad'arčia ako Nemci...".66 Navyše, v blízkosti metropoly, akou boli Košice, mohla mad'arizácia Židov prebiehat' ešte intenzívnejšie. Napriek tomu však Tibor Bohdanovský do zápisu svojho vojenského záznamu uviedol, že jeho materinským jazykom je slovenčina. ${ }^{67}$ Tento rozpor sa pokúsime vysvetlit'. V čase narodenia Tibora Bohdanovského bolo obyvatel'stvo Bohdanoviec z väčšiny slovenské (1924), ${ }^{68}$ koncentrované však najmä medzi miestnymi katolíkmi, pričom veriaci reformovanej krest'anskej cirkvi (kalvíni) rozprávali prevažne po mad'arsky. ${ }^{69} \mathrm{Z}$ doterajších vedomostí a spomienok pamätníkov predpokladáme, že židovské obyvatel'stvo v Bohdanovciach bolo minimálne dvojjazyčné, so znalost'ou mad'arčiny a slovenčiny, s dôležitejšou pozíciou mad'arčiny. Ďalším z faktov naznačujúcich mad'arčinu ako jeho materinský jazyk je, že Tibor nebol jediný z troch súrodencov, ktorým rodičia dali mad'arské mená, ked'že d'alší z jeho bratov sa volal Zoltán. ${ }^{70}$ Vyučovacím jazykom v miestnej l'udovej škole, ktorú Tibor Bohdanovský, vtedy ešte ako Schwarz, navštevoval, bola slovenčina. Na základe vyššie uvedeného predpokladáme, že jeho materinským jazykom mohla byt' mad'arčina, ktorú o niekol'ko rokov v súvislosti s navštevovaním školy a začleňovaním sa do susedskej pospolitosti doplnila slovenčina a ktorú neskôr, zrejme z kariérnych dôvodov, uvádzal aj ako svoj materinský jazyk. Navyše, Tibor v poslaneckom dotazníku i vo vojenskom zázname

\footnotetext{
${ }^{64}$ VHA TT, fond osobných spisov, 1920. Tibor Bohdanovský - Dotazník.

${ }^{65}$ BOHDANOVSKÝ, Tibor: A falvak újjászúletésének három étvizede. (Tri desat'ročia znovuzrodenia dediny). In: Szabad Földmüves. 1979, roč. 30, č. 3, s. 1, 12. BOHDANOVSKÝ, Tibor: Jó munkával a köz érdekében. (Dobrou prácou za záujmy spoločnosti). In: Szabad Földmüves. 1980, roč. 31, č. 52, s. 4. BOHDANOVSKÝ, Tibor: Nehány gondolat az országos mezögazdasági szervezet létrehozásához. (Niekol'ko myšlienok k utvoreniu celoštátnej organizácie pol'nohospodárov). In: Szabad Földmüves. 1968. 20. 4. 1968, s. 1.

${ }^{66}$ BEKSICS, Gusztáv: Mad'arizácia a pomad'arčovanie. Bratislava : R-COOK, 2000, s. 57.

${ }^{67}$ VHA TT, fond osobných spisov, 1920. Tibor Bohdanovský - Evidenčný list k vojenskej knižke.

${ }^{68}$ Soznam obcí župy Košickej a jej administratívne rozdelenie. Košice, s. 18.

${ }^{69}$ Rozhovor s Evou Kadukovou. Bohdanovce, 9. 6. 2020. Rozhovor s Teréziou Vasilovou. Bohdanovce, 21.12. 2019.

${ }^{70}$ Druhý brat Tibora Bohdanovského sa volal Ladislav, čo je vo verzii „Laci“, resp. László tiež medzi Mad'armi rozšírené.
} 
zhodne na všetkých miestach uviedol slovenskú národnost'. To mohlo byt' dôležité najmä v prvých rokoch po ukončení druhej svetovej vojny v súvislosti s postojom vtedajšej štátnej moci k mad'arskej menšine (Benešove dekréty), ked' „Predsedníctvo SNR 18. mája 1945 (vrátane zástupcov KSS) prijalo rozhodnutie o zákaze prijímania Mad'arov do politických strán. [...] Pokial' sa už v stranách nachádzali, malo sa ich členstvo suspendovat'“. Tento postoj si osvojila aj samotná Komunistická strana Slovenska, ktorá „po vyhlásení Košického vládneho programu podporovala všetky opatrenia zamerané na elimináciu pozícií mad'arskej menšiny (odsun, výmena obyvatel'stva, reslovakizácia). [...] V októbri 1946 bolo v KSS evidovaných iba 514 Mad'arov. V skutočnosti ich bolo viac [...] Väčšina $z$ nich sa v tom čase zrejme hlásila $k$ slovenskej národnosti“.71

\section{Záver}

Tibor Bohdanovský, zrejme najvýznamnejší rodák z obce Bohdanovce ned'aleko Košíc, prežil svoju mladost' vo vel'mi zložitom období politických zmien v medzinárodnom prostredí. Bezprostredný vplyv na jeho život mala nielen Viedenská arbitráž a následné prekresl'ovanie hraníc, po ktorom sa stal obyvatel'om Mad'arska, ale trpel predovšetkým ako obet' holokaustu. Neskôr však aktívne bojoval na strane osloboditel'skej armády a podiel'al sa na nástupe d'alšej totality. Participujúc na nespravodlivostiach komunistického režimu sa tak z prenasledovaného stal prenasledujúci a ten, kto trpel pod jarmom jednej totality, sa po jej páde aktívne podiel'al na utlačovatel'skom režime d'alšej totality. Predpokladáme, že v prípade Tibora Bohdanovského nešlo o žiaden akt odplaty, ale o jednoduchý oportunizmus a snahu zabezpečit' si spoločenskú pozíciu a moc za každú cenu. Tento pozoruhodný kariérny úspech dosiahol navyše napriek trom stigmám: bol Židom, mad'arsky hovoriacim od malička a synom živnostníka. Išlo teda o vel'mi schopného jedinca, schopného presadit' sa aj v t'ažkej situácii a, žial', bez ohl'adu na morálku či zapretie vlastnej identity. Navzdory nepriaznivým etnickým predpokladom, pôvodu i mimoriadne zložitej spoločensko-politickej situácii, dokázal totiž Tibor Bohdanovský nielen prežit', ale v profesionálnom živote aj mimoriadne uspiet' a stat' sa aktívnou súčast'ou a spolutvorcom nedemokratického režimu, ktorý so všetkými svojimi temnými stránkami trval na našom území vyše 40 rokov, predsa je však neoddelitel'nou súčast' našich dejín.

\footnotetext{
${ }^{71}$ PEŠEK, J.: Komunistická strana Slovenska - dejiny politického subjektu, s. 17 - 18.
} 